Т. М. Спільник,

кандидат філологічних наук, доцент rosinka725@gmail.com

ORCID: 0000-0002-1913-010X

Я. О. Мокрій,

старший викладач

(Національна академія Національної гвардії України, м. Харків) yanamokriy@gmail.com

ORCID: $0000-0002-4069-6036$

\title{
МОЖЛИВОСТІ ПРАКТИЧНОГО ВИКОРИСТАННЯ СМАРТФОНІВ І ПЛАНШЕТІВ НА ЗАНЯТТІ 3 ІНОЗЕМНОЇ МОВИ У ВИЩОМУ НАВЧАЛЬНОМУ ЗАКЛАДІ
}

Стаття присвячена виявленню можливостей практичного використання смартфонів і планшетів на занятті з іноземної мови у вищому навчальному закладі. Наведено приклади практичних завдань $з$ використанням мобільних додатків, а також технічного оснащення мобільних пристроїв. Доведено, щзо виконання завдань, які передбачають роботу зі смартфонами та планшетами на занятті з іноземної мови, спонукає студентів до творчості, сприяє розвитку комунікативних умінь. Обгрунтовано необхідність поєднання застосування мобільних пристроїв з традиційними методами навчання.

Ключові слова: заняття з іноземної мови, комунікативні уміння, мобільні пристрої, планшети, практичні завдання, смартфони, технічне оснащення.

Постановка проблеми. Мобільні пристрої, як-то: мобільні телефони, смартфони, планшети, уже давно ввійшли в повсякденне життя пересічної людини. Компактні, легкі, зручні у використанні, багатофункціональні - усі ці якості сприяли тому, що для багатьох людей вони стали надійними помічниками в різних життєвих ситуаціях. Будучи засобом усної (розмови по телефону) та письмової (СМС повідомлення, електронна пошта) комунікації, міні-комп'ютером, вони є універсальним i поліфункціональним пристроєм.

За статистикою з кожним роком кількість користувачів смартфонів збільшується [1], а серед молодих людей їх популярність узагалі важко переоцінити. Саме тому ігнорування мобільних пристроїв на занятті 3 іноземної мови не доцільне. 3 огляду на це постає питання, як раціонально та ефективно можна використовувати мобільні телефони, смартфони, планшети на занятті з іноземної мови.

Аналіз основних наукових досліджень і публікацій. У науковій літературі навчання, під час якого використовуються мобільні пристрої, називають мобільним навчанням (M-Learning). Теоретичні аспекти мобільного навчання неодноразово знаходили висвітлення в працях як вітчизняних (С. Семеріков, Ю. Триус, Н. Рашевська, В. Ткачук, І. Золотарьова, А. Труш та ін.), так і зарубіжних (Дж. Тракслер, Г. Дадні, В. Куклєв, Х. Мічіан, С. Титова, А. Авраменко та ін.) науковців. Проте відчувається брак праць, у яких би розглядалися питання практичного застосування мобільних пристроїв на занятті з іноземної мови.

Мета статті - виявити можливі шляхи практичного використання смартфонів і планшетів на занятті 3 іноземної мови у вищому навчальному закладі.

Аналіз публікацій, присвячених досліджуваному питанню, виявляє єдність у поглядах науковців на те, що використання мобільних пристроїв на занятті з іноземної мови сприяє підвищенню мотивації та організації автономного навчання студентів $[2 ; 3 ; 4 ; 5]$.

Виявляючи потенціал мобільних пристроїв як засобів вивчення іноземної мови, К. В. Капранчикова зазначає, що "регулярне використання мобільних технологій у процесі навчання іноземної мови сприятиме кращому формуванню аспектів іншомовної комунікативної компетенції" [6: 93].

На думку К. Хан, за умови правильного використання планшетів заняття з іноземної мови мають дидактичний потенціал передусім у таких видах мовленнєвої діяльності, як говоріння та аудіювання. За словами дослідниці, особи, які навчаються, можуть слухати на планшеті аудіозаписи чи переглядати короткі фільми в тому темпі, який відповідає рівню знання мови. До того ж вони мають можливість декілька разів прослуховувати ті частини тексту, які викликають труднощі [7].

Варто зазначити, що порівняно із зарубіжними країнами, у нашій країні недостатньо приділено уваги використанню потенціалу мобільних пристроїв на занятті 3 іноземної мови. Так, у Німеччині організовуються семінари, конференції, на яких викладачі вищих навчальних закладів, учителі шкіл обговорюють можливості раціонального використання смартфонів і планшетів на заняттях з іноземної мови. Крім того, стартують експериментальні проекти, у межах яких здійснюються дослідження щодо того, чи допомагають мобільні пристрої вивчати іноземну мову. Наприклад, пілотний проект ГетеІнституту мав за мету перевірити, як використання планшетів на занятті з німецької мови, як іноземної, сприяє розвитку навичок аудіювання та говоріння в осіб, які навчаються. У рамках проекту було

(C) Спільник Т. М., Мокрій Я. О., 2017 
проаналізовано, чи впливає використання мобільних пристроїв на мотивацію цих осіб, і яка роль викладача на таких заняттях [7].

Виклад основного матеріалу. Основна мета заняття з іноземної мови - стимулювати комунікативну активність студентів. Саме комунікації в повсякденному житті молоді люди приділяють найбільше уваги: вони пишуть один одному повідомлення, спілкуються в соціальних мережах, щось коментують, розміщують інформацію. Зважаючи на те, що таке спілкування з використанням смартфонів і планшетів для молоді увійшло у звичку, виникає необхідність дати шанс цим мобільним пристроям бути інтегрованими в контекст заняття 3 іноземної мови. Інакше кажучи, замість того, щоб реагувати на ввімкнений на занятті мобільний телефон чи смартфон категоричною забороною, варто поглянути на ситуацію з іншого боку й подумати, як можна поєднати заняття з іноземної мови під керівництвом викладача $з$ формою роботи, де був би застосований мобільний пристрій.

Смартфони та планшети пропонують безліч можливостей креативно організувати заняття з іноземної мови. Доповнюючи роботу з підручником, вони удосконалюють традиційні форми навчання. Зміна ж форм роботи на занятті із застосуванням мобільних пристроїв може позитивно вплинути на мотивацію студентів.

Смартфони (планшети) є гарними помічниками в організації роботи в групах та індивідуальної роботи студентів як на занятті, так і за межами аудиторії. Крім того, мобільні пристрої допомагають у застосуванні диференційованого підходу до навчання. Зокрема, ідеться про те, що студенти отримують завдання залежно від індивідуальних особливостей та відповідно до свого рівня володіння іноземною мовою. Виконання цих завдань із застосуванням смартфонів дає змогу їм працювати у своєму темпі, а це, у свою чергу, допоможе подолати страх перед вивченням іноземної мови та сприятиме підвищенню мотивації.

Спостереження за роботою студентів на занятті з іноземної мови доводять, що з появою смартфонів $\mathrm{i}$ планшетів для перекладу незнайомих слів вони все рідше користуються паперовими словниками й надають перевагу електронним, у тому числі й Online-словникам. Найпопулярнішими серед них $є$ зокрема такі: ABBYY Lingvo, Leo, Pons, перекладач Google. На перший погляд, у роботі зі словником немає нічого складного, головне, щоб можна було знайти переклад потрібного слова. Проте не всі словники однакові. Саме тому важливо вчити студентів працювати із словниками, пояснюючи, у чому переваги чи недоліки різних Online-словників, а також, як варто їх раціонально використовувати.

Як зазначалося, можливості використання мобільних пристроїв на занятті з іноземної мови дуже різноманітні. Водночас такі заняття повинні бути ретельно спланованими. Передусім варто визначитись, iз якою метою будуть застосовані смартфони й планшети на занятті та які компетенції будуть формуватися під час виконання запропонованих завдань.

Розглянемо завдання, виконання яких передбачає використання мобільних пристроїв.

Відомо, що вивчення мови не можливе без вивчення нової лексики. Так, на занятті з німецької мови для опрацювання лексичного матеріалу можна запропонувати студентам у невеликій групі виконати наступне завдання: Створіть за допомогою мобільного додатку My Picture Books електронний ілюстрований словник до теми "In der Stadt". Оберіть одну з поданих тем: "Verkehr", "Gebäиde", "Unterhaltung", "Betriebe", "Geschäfte", "Gaststätte". Додайmе фото з відповідними об'єктами. Використовуючи електронний словник (ABBYY Lingvo, Leo, Pons) чи перекладач Google, перекладіть німецькою мовою назви об'єктів та запишіть їх поряд із картинкою. 3'єднайте окремі частини словника в один документ. Варіантами для самостійного виконання завдань з використанням мобільних додатків My Picture Books чи Pic Collage, як на занятті, так і в позааудиторний час, при вивченні теми, наприклад "Das Wetter", можуть стати такі: I. Здійсніть спостереження за погодою. Використовуючи мобільний додаток My Picture Books або Pic Collage, складіть німецькою мовою звіт про погоду. II. Знайдіть в Інтернеті прогноз погоди у Вашому місті на наступний день. За допомогою мобільного додатка My Picture Books або Pic Collage складimb прогноз погоди. Звіт про погоду чи складений прогноз студенти презентують на занятті. Працюючи з мобільним додатком Pic Collage, студенти можуть скласти також фотоколаж на тему "Mein Traumhaus". Пропонуючи такі завдання, студентів не варто обмежувати у творчості. Вони самі здійснюють пошук потрібної інформації, обдумують пояснення до дібраних фото й в усній формі презентують свій доробок в аудиторії. Виконання таких завдань дає змогу реалізувати творчий потенціал студентів, удосконалити їх комунікативні вміння, формувати навички самостійної пізнавальної діяльності.

Одним із варіантів завдань для роботи з лексичним матеріалом може стати створення ментальної карти 3 використанням мобільного додатка Simple Mind Free, наприклад: За допомогою мобільного додатка Simple Mind Free створіть ментальну карту до теми "Der Urlaub". Окрім названого мобільного додатка, для створення ментальних карт можна використовувати також й інші додатки, як-от: Schematic Mind Free, Mind Meister та ін.

Ментальна карта (синонімічні назви - інтелектуальна карта, інтелект-карта, карта-пам'яті, карта думок, діаграма зв’язку, асоціативна карта, майндмэп) - це спосіб структурування інформації, що 
передбачає розгалуження ідей-асоціацій від основного поняття. За допомогою створення ментальної карти на занятті з іноземної мови можна опрацьовувати нові слова до теми чи повторювати в такий спосіб вже відому лексику.

Метод ментальної карти можна застосувати також при роботі з текстом, як у завданні: Прочитайте текст "Feste in Deutschland". За допомогою мобільного додатка Simple Mind Freе створіть до тексту ментальну карту. На основі ментальної карти, розкажіть про свята в Німеччині.

Технічне оснащення мобільних пристроїв, а саме вмонтована камера, дає змогу запропонувати студентам завдання, які сприятимуть розвитку комунікативної компетенції. Одним із таких завдань може бути запис інтерв'ю на подану тему, а саме: Зніміть фільм на тему "Meine Universität". Утворіть групи, які складатимуться з трьох учасників (студент, журналіст, оператор). Оберіть для своєї групи одну 3 поданих тем: "Der Weg zur Universität", "Fakultäten", "Meine Fakultät", "Inhalt und Aufbau des Studiums", "Studentisches Leben". Запишіть у групі інтерв'ю на обрану тему. 3'єднайте інтерв'ю всіх груп в один фільм.

Функції камери можуть бути застосовані також для здійснення самостійного проекту поза межами аудиторії. Так, одним із завдань при вивченні теми "Meine Stadt" може бути завдання зняти фільм, у якому ішлося б про визначні місця в рідному місті. Варіантом цього завдання може стати створення фоторепортажу, коли студенти фотографують на смартфони визначні місця свого міста, а потім на занятті у вільній формі презентують ці фото, пояснюючи, що на них зображено. У такий спосіб студенти вчаться описувати об’єкти, опрацьовують і повторюють лексичний матеріал до теми, тренуються в постановці питань та відповіді на них. Під час вивчення теми "Spezialitäten" для самостійного проекту студентам можна запропонувати завдання, де вони повинні будуть приготувати національну українську страву. Приготування страви 3 поясненням повинне бути крок за кроком записане на камеру смартфону чи планшета або кожен етап приготування страви сфотографований на мобільний пристрій. На занятті студенти показують знятий фільм. Якщо ж страва задокументована у формі фото, то на основі цих фото вони розповідають про іiі приготування.

Функції аудіопрогравача та диктофона можуть бути використані, наприклад, на початковому етапі вивчення мови для тренування правильної вимови, як на занятті в невеликих групах, так і самостійно. Працюючи над фонетичними вправами, студенти спочатку слухають оригінальний текст, а потім самі читають цей текст на диктофон. Після цього їм можна запропонувати прослухати запис, порівняти надиктований текст і оригінальний, звернути увагу на ті моменти у вимові чи в інтонації, які відрізняються від оригінального тексту. За наявності помилок у вимові текст надиктовують ще раз. Завданням для виконання в позааудиторний час з використанням функції диктофона при вивченні теми "Literatur" може стати створення радіопостановки, над якою студенти працюють у невеликих групах: Оберіть уривок з художнього твору (байку, вірш), який би Ви хотіли озвучити. Напишіть сценарій до радіопостановки зі словами автора та дійових осіб. Радіопостановку повинні супроводжувати якісь звуки чи иум. Ці звуки відповідно до своїх місиь також повинні бути описані в сценарії. Створення радіопостановки розвиває фантазію, спонукає студентів до творчості. Окрім того, у цьому проекті студенти тренуються в такому виді мовленнєвої діяльності, як читання. У них формуються вміння самостійного пошуку, аналізу та добору необхідної інформації, навички роботи в групі.

Одним із можливих завдань для розвитку навичок аудіювання з використанням функцій аудіо- чи відео програвача може стати прослуховування коротких аудіотекстів чи перегляд відеофільмів. Як правило, такі завдання призначені для роботи в парах. Студентам для виконання цього завдання потрібні навушники. Перш ніж запропонувати завдання студентам, викладач на сайті, наприклад Deutsche Welle (http://www.dw.com), добирає декілька аудіоматеріалів чи відеофільмів, ураховуючи рівень володіння мовою студентів. На занятті викладач повідомляє посилання в Інтернеті, за яким студенти знаходять відповідний матеріал. Текст студенти можуть слухати частинами, незрозумілі моменти прослуховувати декілька разів. На основі прослуханого тексту чи переглянутого відео студенти в парах виконують завдання.

Висновки та перспективи подальших досліджень. Як можна бачити, мобільні пристрої пропонують безмежні можливості для організації заняття з іноземної мови. Беззаперечним є той факт, що робота зі смартфонами та планшетами на занятті з іноземної мови дає змогу працювати 3 автентичними матеріалами, спонукає студентів до творчості, мобільності, гнучкості в мисленні. Завдання, що передбачають використання мобільних пристроїв, сприяють розвитку комунікативної, міжкультурної, лінгвокраїнознавчої, інформаційної, когнітивної, а також соціальної компетентностей. Проте попри все це мобільні пристрої не можуть замінити ані підручника, ані пояснення викладача. До того ж у студентів не повинно складатися враження, що мобільні пристрої стануть єдиним засобом у вивченні іноземної мови й зникне потреба працювати з підручником чи звернутися до викладача.

Таким чином, робота 3 мобільними пристроями на занятті з іноземної мови сприяє впровадженню інноваційних форм викладання i, так би мовити, дидактично розширює традиційні форми навчання. К. Мейбергер зауважує, коли приймається рішення щодо інтеграції мобільних пристроїв у навчальний 
процес, йдеться про "як...так i", а не про "або ... або" [8: 5]. Іншими словами, на занятті варто поєднувати використання мобільних пристроїв із напрацьованими методами навчання. Завдання, подані в підручнику з розвитку усіх видів мовленнєвої діяльності (читання, говоріння, письмо, аудіювання), студенти також можуть виконувати на своїх смартфонах і планшетах. Викладач супроводжує цей процес: пояснює, допомагає, перевіряє виконання завдань, консультує тощо.

Не можна обійти увагою також те, що ефективність використання смартфонів і планшетів на занятті 3 іноземної мови залежить передусім від технічної грамотності викладачів. На жаль, педагоги часто не мають чітких уявлень про можливості сучасної мобільної техніки й про шляхи використання потенціалу мобільних пристроїв на занятті з іноземної мови.

Перспективою подальших досліджень із практичного використання смартфонів і планшетів на занятті з іноземної мови у вищому навчальному закладі може стати розробка, опис та оптимізація завдань для позааудиторної самостійної роботи студентів.

\section{СПИСОК ВИКОРИСТАНИХ ДЖЕРЕЛ ТА ЛІТЕРАТУРИ}

1. Кількість користувачів смартфонів в Україні зросла на $150 \%$ [Електронний ресурс]. - Режим доступу: https://www.epravda.com.ua/news/2016/09/12/605197/.

2. Титова С. В. Эволюция средств обучения в преподавании иностранных языков : от компьютера к смартфону / С. В. Титова, А. П. Авраменко // Вестник Московского университета. - Серия 19. Лингвистика и межкультурная коммуникация. - 2013. - № 1. - С. 9-21.

3. Титова С. В. Мобильное обучение сегодня: стратегии и перспективы [Електронний ресурс] / С. В. Титова. Режим доступу : http://www.ffl.msu.ru/research/vestnik/1-2012-titova.pdf

4. Steinhart M. Vernetzter Unterricht : Smartphones und Tablets sinnvoll nutzen [Електронний ресурс]. - Режим доступу : http://informationszentrum-mobilfunk.de/vernetzter-unterricht-smartphones-und-tablets-sinnvoll-nutzen.

5. Strasser Th. Mobiles Lernen im DaF-Unterricht Smartphones, Tablets und Со [Електронний ресурс]. - Режим доступу : https://www.goethe.de/de/spr/mag/20744244.html.

6. Капранчикова К. В. Мобильные технологии в обучении иностранному языку студентов нелингвистических направлений подготовки / К. В. Капранчикова // Язык и культура. - Вып. № 1 (25). - 2014. - С. 84-94.

7. Hahn K. Tablets im DaF-Unterricht Das digitale Klassenzimmer [Електронний ресурс]. - Режим доступу : https://www.goethe.de/de/spr/mag/20516230.html.

8. Mayrberger K. Unterwegs lernen? Mobile Endgeräte im Unterricht / K. Mayrberger // Praxis Fremdsprachenunterricht: die Zeitschrift für das Lehren und Lernen fremder Sprachen. - Basisheft [Themenheft Mobiles Lernen]. - Heft 1. - München : Cornelsen Verlag GmbH, 2013. - S. 5-7.

\section{REFERENCES (TRANSLATED \& TRANSLITERATED)}

1. Kil'kist korystuvachiv smartfoniv v Ukraini zrosla na $150 \%$ [Number of Smartphones Users in Ukraine Has Increased by $150 \%$ ] [Elektronnyi resurs] https://www.epravda.com.ua/news/2016/09/12/605197/.

2. Titova S. V. Evolutsiia sredstv obucheniia v prepodavanii inostrannykh yasykov : ot kompiutera $\mathrm{k}$ smartfonu [Evolution of Means of Education in Foreign Languages Teaching : from Computer to Smartphone] / S. V. Titova, A. P. Avramenko // Vestnik Moskovskogo universiteta [Moscow University Journal]. - Seriia 19. Lingvistika i mezhkul'turnaia kommunikatsiia. - 2013. - № 1. - C. 9-21.

3. Titova S. V. Mobil'noe obuchenie segodnia : strategii i perspektivy [Mobile Teaching Today: Strategies and Perspectives] [Elektronnyi resurs] - Rezhym dostupu : http://www.ffl.msu.ru/research/vestnik/1-2012-titova.pdf.

4. Steinhart M. Vernetzter Unterricht : Smartphones und Tablets sinnvoll nutzen [Elektronnyi resurs] - Rezhym dostupu : http://informationszentrum-mobilfunk.de/vernetzter-unterricht-smartphones-und-tablets-sinnvoll-nutzen.

5. Strasser Th. Mobiles Lernen im DaF-Unterricht Smartphones, Tablets und Co [Elektronnyi resurs] - Rezhym dostupu : https://www.goethe.de/de/spr/mag/20744244.html.

6. Kapranchikova K. V. Mobil'nye tekhnologii v obuchenii inostrannomu yazyku studentov nelingvisticheskikh napravlenii podgotovki [Mobile Technologies in Foreign Languages Teaching of Students of Nonlinguistic Directions of Education] / K. V. Kapranchikova // Yasyk i kultura [Language and Culture]. - Vyp. № 1 (25). 2014. - C. 84-94.

7. Hahn K. Tablets im DaF-Unterricht Das digitale Klassenzimmer [Elektronnyi resurs] - Rezhym dostupu: https://www.goethe.de/de/spr/mag/20516230.html.

8. Mayrberger K. Unterwegs lernen? Mobile Endgeräte im Unterricht / K. Mayrberger // Praxis Fremdsprachenunterricht: die Zeitschrift für das Lehren und Lernen fremder Sprachen. - Basisheft [Themenheft Mobiles Lernen]. - Heft 1. - München : Cornelsen Verlag GmbH, 2013. - S. 5-7.

\section{Спильник Т. Н., Мокрий Я. О. Возможности практического использования смартфонов и планшетов на занятии по иностранному языку в высшем учебном заведении.}

Статья посвящена определению возможностей практического использования смартфонов и планшетов на занятии по иностранному языку в высшем учебном заведении. Приводятся примеры практических заданий с использованием мобильных приложений, а также технического оснащения мобильных устройств. Установлено, что выполнение заданий, которые предусматривают работу на смартфонах 
и планшетах на занятии по иностранному языку, способствует развитию творческого мышления, коммуникативных умений. Обосновано необходимость объединения применения мобильных устройств с традиционными методами обучения.

Ключевые слова: занятия по иностранному языку, коммуникативные умения, мобильные устройства, планшеты, практические задания, смартфоны, техническое оснашение.

\section{Spilnyk T. N., Mokrii Ya. O. Possibilities of Practical Use of Smartphones and Tablets at the Foreign Language Lessons in Higher School.}

The article deals with detection of possibilities of practical use of smartphones and tablets at the foreign language lessons in higher school. The author gives examples of practical assignments with use of mobile applications and techniques of mobile devices as a camera, a dictaphone or a sound player. These assignments can be proposed to students in order to use both at the lesson and for creation their own projects. In order to work out topic vocabulary variations of assignments with use of such mobile applications are described. Functions of camera are recommended to use for performing such tasks as making a film or creating a photo spread. The author suggests using functions of a dictaphone at the initial stage of learning a language for training correct pronunciation both in small groups and on one's own. The author proposes creation of radio show as an example of the assignment with use of functions of a dictaphone for creating independent projects. It is found out that by using such assignments students form ability of independent search, analysis and selection of necessary information and skills of working in groups. It is determined that work with smartphones and tablets at the foreign language lessons gives an opportunity to deal with authentic materials and it induces students to creative work, mobility and mentality pliability. The author proves that assignments with use of mobile devices favour the development of communicative, cross-cultural, linguistic-cultural, informational, cognitive and also social competences. The author also grounds the necessity of combination of mobile devices use and traditional methods of education.

Key words: foreign language lessons, communicative skills, mobile devices, tablets, assignments, smartphone, technique. 